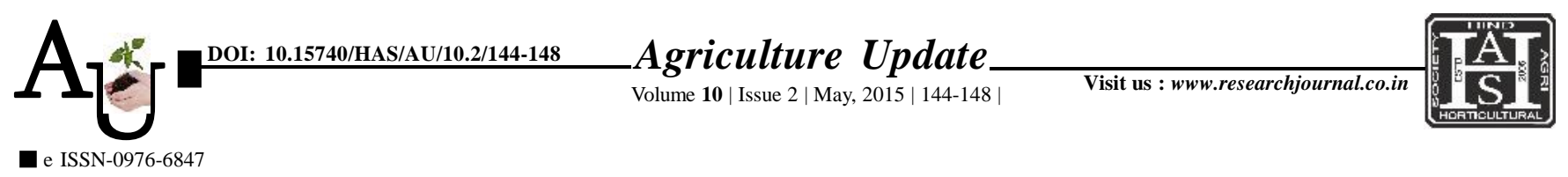

\title{
Reserach Aвтісl: A study on knowledge and adoption level of improved animal husbandry practices by milk producer in Vadodara district of Gujarat
}

\author{
口 B.L. DHAYAL*, J.P. MEENA, M.L. PATEL AND B.M. MEHTA
}

Article Chronicle: Received : 13.03.2015;

Revised : 26.03.2015; Accepted : 11.04.2015

KEY WoRDS: Knowledge, Adoption level, Animal husbandry practice, Milk producer/ Livestock rearers

SUMMARY : Present study was carried out in Vadodara district of middle Gujarat. The animal husbandry is one of the important sources of livelihood of rural people. For data collection two blocks Waghodiya and Sankheda were selected from the district. Five villages of each selected block and 10 livestock rearer's families from each selected village were randomly selected. It can be inferred that great majority (98\%) of milk producers have good knowledge of regular cleaning of cattle shed and 96 per cent of the farmer have good knowledge regarding water to be given to a dairy animals. More than 80 per cent farmers have knowledge about heat detection and A. I. to their animals. Lowest number of surveyed famers (26\%) have knowledge of regular de-worming to the calf and 30 per cent farmer have knowledge of purchasing animals after veterinary check up followed by knowledge of enrichment of poor qualify roughages by urea treatment (34). 36 per cent farmers have knowledge of cutting and disinfections of naval cord with tincture iodine. Also revealed that majority of the milk producers (94\%) are adopting hygienic disposal of placenta followed by quick delivery of milk to the village Co-operative immediately after milking (96\%). Lowest number of the framers (2\%) showed adoption of the regular grooming and enrichment of poor quality roughages by urea treatment (2\%) and 4 per cent farmers followed maintenance of breeding, feeding, health care and production records.

How to cite this article : Dhayal, B.L., Meena, J.P., Patel, M.L. and Mehta, B.M. (2015). A study on knowledge and adoption level of improved animal husbandry practices by milk producer in Vadodara district of Gujarat. Agric. Update, 10(2): 144-148.

Author for correspondence :

\section{B.L. DHAYAL}

Krishi Vigyan Kendra, VADODARA (GUJARAT) INDIA

Email: dhayalextn@ yahoo.co.in

See end of the article for authors' affiliations 